\title{
球技場吊り屋根鉄骨の製作・建 方施工管理に関する報告
}

\section{REPORT ON THE FABRICATION \& CONSTRUCTION OF THE SUSPENDED STEEL-FRAME ROOF OF A SOCCER STADIUM}

\section{Osamu FUKUI — $* 1 \quad$ Kumehiko KOHNO - $* 2$ Ikuhide SHIBATA - *3}

This paper reports the fabrication and construction of the fixed roof of Toyota stadium. The fixed roof looks like a crescent moon and covers the main \& back stands. It's composed of keel truss, sub-truss, combined beam and horizontal brace. This paper describes the control process of the fabrication, referring to drawing, casted steel, optimum method of welding, combination of various joint plates.

Also this paper describes the erection process of the roof on site.

\section{1.はじめに}

本報告書は矢作緑地施設整備工事（豊田スタジアム建設工事）に おける吊り屋根鉄骨の製作・建方施工管理に関する報告である。

屋根形状は球技場の円形客席スタンドの上部に、呪を伏せたよう な三日月状の屋根である。固定屋根はメインスタンド、バックスタ ンド上部に独立して設置され、スタジアム四隅に設けられたマスト からケーブルにて吊る構造である。また、東西の固定屋根を跨ぐ形 で下部のフィールドを覆うように開閉式可動屋根が設置される。

固定屋根は三日月の弦の位置に長さ $220 \mathrm{~m}$ に及ぶキールトラスが あり、それに直交する形で最長 $60 \mathrm{~m}$ 、片側 11 台のサブトラスを接 合し、サブトラス閒に繁ぎ梁及び水平ブレースを配置して、屋根棈 面を構筑している。（図 1 参照）

サブトラスのキールトラス他端側にはルーフサポートが設けら れ、下部スタンド鉄骨に剛接され、屋根鉄骨の水平力を下部構造に 伝達している。また、ルーフサポートとサブトラスはピン接合にな っており、固定屋根の温度変形他に追従するための可撓性を確保し ている。

キールトラスは $5,000 \times 6,250$ の断面を有する三角形状の鋼管トラ スで構成されている。建方時を考慮し、全体を9分割し、長さ25 $38 \mathrm{~m}$ 、重量 84〜125 t の地組ニニットとしている。

サブトラスは弓型の形状で、屋根面と取合う直線部をH形䤡、曲 線部を銅管で樓成した成 $5,500 \mathrm{~mm}$ の平面トラスである。約 $14 \mathrm{~m}$ 間 隔で、屋根面を境に上反り下反りのトラスが交互に配置されている。

マストは最大板厚 $70 \mathrm{~mm} 、 60 \mathrm{~kg}$ 級高張力鋼板（北側 2 本）、53kg 級高張力鎆板（南側 2 本）を最大 $\phi 3500 \mathrm{~mm}$ の円筒形に曲げ加工し

\footnotetext{
*1 大成建設㑣名古屋支店建築部 課長

( 450-6047 名古屋市中村区名駅1-1-4 JR セントラルタワーズ)

*2 大成建設侏名古屋支店建築部 工事長

*3 オーヴアラップアンドパートナーズジャパンリミテッド
}

て溶接接合した長さ約 $90 \mathrm{~m}$ の円柱である。単品重量約 $450 \mathrm{t} /$ 本の 独立柱で、柱脚部には球座を有している。

ケーブルは素線 $\phi 7 \mathrm{~mm}$ の $160 \mathrm{~kg}$ 級ピアノ線を張力に忘じて、283 〜499 本束ねたものを使用している。工場製作時に所定長さに加工 され、端部金物と一体化されたものを現場にて展開、架設、毉張し ている。C B 1〜4はキールトラス側上吊り、C B 5、6はバック ステー側の上吊りケーブルで、C B 11 1、1 2 は地震時、強風時に キールトラスの変形を抑えるタイダウンケーブルである。

工事量として総重量約 $8,650 \mathrm{t}$ (ケーブル共)屋根面積約 $20,000 \mathrm{~m}^{2}$ に及ぶ大規模な吊り屋根鉄骨工事である。
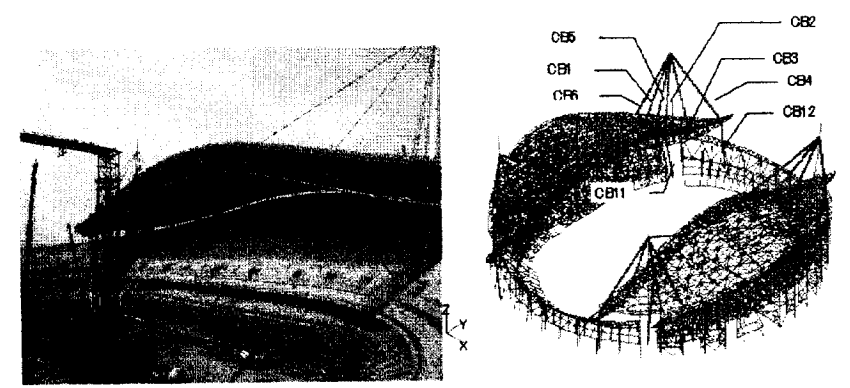

図 1 固定屋根外観及び架構概念図

\section{2. 製作管理}

2ー1ケーブル定着に対する鋳銿品形状決定と製作手順

今回鋳鋼品を使用した主な部位は下記の通りである。

・マストの柱脚部及び柱頭部

・キールトラスのケーブル取合部

・ルーフサポートのケーブル取合部

*1 Manager, Building Construction Department, Nagoya Branch, Taisei Corporation

*2 General Manager, Building Construction Department, Nagoya Branch, Taisei Corporation

*3 Ove Arup \& Partners Japan Limited 
・サブトラスの外周端ピン接合部

総重量で約 800ton 単品最大重量で約 50ton の鋳銅品であった。 鋳銅品の製作手順は、概ね下記のフローに従って行った。

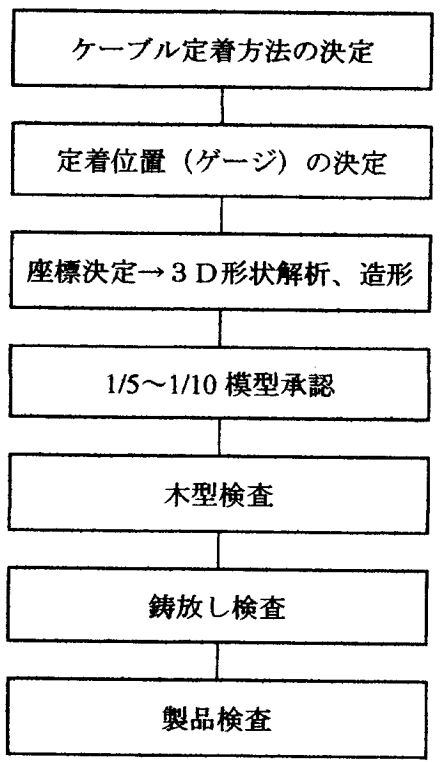

ピン定着、ボルトナット定着 支圧版定着等

キールトラスゲージ芯合せ等

ケーブル入射角解析 集合部材のスタッブ仕様決定

造方案、収縮率の確証 押し晹位膡の確認、補修仕様

㭪修ショット部分の粗さ確認

機械加工部の寸法精度確認 材料試験（特にシャルピー）

ケーブル端部の定着方法は、意匠性、納り、祭張方法等より、マ スト頂部はボルトナット定着 (図 2 参照)、多端側は支圧版定着 (図 3参照）としている。また、キールトラスの吊上げケーブルとタイ ダウンケーブルの定着点は、鉡鋼による一体部品である。
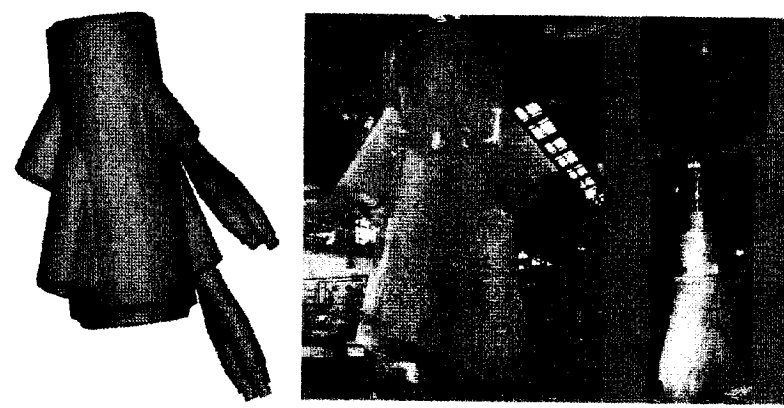

図 2 マスト頂部鉐銿品 $3 \mathrm{D}$ 造形図、製品外観、定着金具類外観
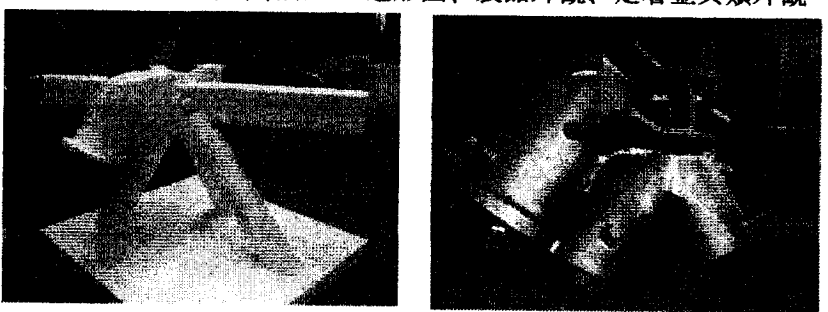

図3 ルーフサポートのケーブル定着鋳龬品の模型と製品外観

鋳銅品に集合する部材の加工性及ひ溶接性能（曲面取合いのため 曲線加工が必要になったり、鋳鎆本体がマスのため取合い溶接部が 急冷されやすく溶接性能が低下し易い。）を確保するため、通常ス タッブという取合いのための枝出しを一体成形する。したがって、 このような鋳銅品の造形には 3 次元CADによる座標管理、ディテ 一ル検討が不可欠となる。

製品検查として、製品寸法精度と治金的珄質の確認を実施した。 治金的確認として、厚肉部分のU T、出隅部、入隅部のMTと同時 鋳込みピースによる材料試験を行った。

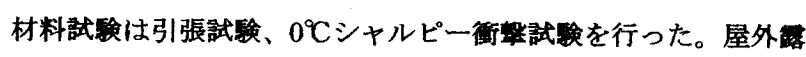
出棬造物のため冬期の低温靭性が問われており、0で最低 $50 \mathrm{~J} か ゙$ 条件であったが、良好な結果を得ることが出来た。

\section{2-2 60kg 級高張力鏩及び鐵艘の溶接計画と模証}

マストの北側 2 本に $60 \mathrm{~kg}$ 級高張力鋮 (SA440B) 板厚 $70 \mathrm{~mm}$ を採 用している。3 m幅の鎆板を半円加工して突合せ溶接する仕様のた め、溶接線には軸線に沿った直線溶接と軸線に直交した円周溶接の 2 種類がある。

溶接施工性試験に先立ち、S AW（サブマージアーク）溶接の予 備試験を実施した。造船の分野では板継ぎ溶接に両面からのS AW 溶接を採用するのは一般的なことであり、今回の物件への適用の可 否について予備検討した。しかし、余盛形状やビード外䧽が意匠的 にやや強調されすぎること、円周溶接での始終端の重なり部の品質 や溶接部の低温時における冶金的特性に疑義があり、採用を見合わ せた。

結局、溶接施工性試験に基き、工場溶接は $\mathrm{CO} 2$ 自動溶接による $\mathrm{X}$ 型開先溶接、現場溶接は $\mathrm{CO} 2$ 半自動溶接によるK型開先溶接を採 用した。溶接施工性試験は冷間曲げ加工压延銅板相互、鋳鎆之圧延 鋼板相互に対し行い、試験項目は、外覞試験、UT試験、化学成分 分析、引張試験、シャルピー衝繋試験 $\left(0^{\circ} \mathrm{C} 、-10^{\circ} \mathrm{C} * \mathrm{BM} 、 \mathrm{DEPO}\right.$ 、 BOND、HAZ*L C Z 方向）、ビッカース硬さ試駿、マクロ試験と した。

圧延鋼材相互のシャルピー衝䡫試験結果は、パス間温度を $230^{\circ} \mathrm{C}$ 以下としたが、溶着金属部分(DEPO)で極小値を示し、0Cでう120 J 程度であった。なお、パス間温度の設定は、S A 440 Bについ ての新日鉄社内技術レポートに基いて決定した。

鋳銅と圧延鋼材溶接部のシャルピー衙慗試釦結果は、予熱 $80^{\circ} \mathrm{C}$ 、 後熱 $600^{\circ} \mathrm{C} * 1 \mathrm{~h}$ 、パス間温度 $230^{\circ} \mathrm{C}$ 以下としたが、BOND、HAZ で

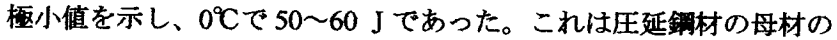
シャルピー值が 200〜250 J あるのに比べ、試験に用いた鋳鋼の靬性 がかなり低いためと考えられる。硬さ試雊結果は、X型開先でビッ カース硬度 260 以下、K型開先で 280 以下、レ型開先で 300 以下程 度であった。

試呀結果を受け、マスト柱脚部の鋂銅取合い容接の開先形状をレ 型からK型開先に変えた。また、製作管理のU T 検査判定値をマス ト中央 $1 / 3$ 部分（地震時に曲げモーメントが極大となる部分）と端 部テーパー部分 $1 / 3$ とで適用基準を変え、板厚方向の表層 $1 / 4$ 部分 と中央 $1 / 2$ 部分でUT検查判定值を変えて適用することにした。

\section{2-3工㙕製作での 3 次元展開と工作图及び仮組立管理}

キールトラス、サブトラスについては、工場での仮組立、現地で の地組を想定して、工作図を組立状況に応じて座標変換する必要が あった。つまり、三角形断面のトラスを正立したまま組立るのは、 トラスが湾曲していることや、三角形の頂点が最下部になるなど組 立用定盤及び地組架台が大掛かりになり、精度も出し難いことが考 えられた。そこで、三角形断面を横倒しして、ラチスを含む斜辺を 定盤に平行になるように座標変換して、組立用工作図とした。ケー ブル定着用鋳銿品の組付け位置及び角度も定盤上の座標、鋳銅品定 着面の定盤となす角度を決定して、適正な地組架台計画を行った。

\section{2-4 高力ボルト摩搳面の組合せ検証}

今回の固定屋根鉄骨は、厚膜型無機ジンクリッチ塗料の部材と要 
鉛メッキ部材の混用で計画された。そこで、上記部材の組合せにお けるボルト接合部のすべり係数試験を実施し、接合部設計に反映し た。つまり、ジンク+ジンク、ジンク+亜鉛メッキには 0.45+F10T（黒 皮ボルト）、亜鉛メッキ+亜鉛メッキには 0.40+F8T（亜鉛メッキボ ルト)のすべり係数及び高力ボルトの組合せを試験により検証した。 また、同時に過大孔の検証と厚板によるリラクゼーションの検証を 行い、孔径 $2 \mathrm{mmUP}$ 及び $4 \mathrm{mmUP} 、 \mathrm{t} 12+\mathrm{t} 22+\mathrm{t} 12 \mathrm{~mm}$ と $\mathrm{t} 22+\mathrm{t} 40+\mathrm{t} 22 \mathrm{~mm}$ の試騟も実施した。試験結果は下表の通りであるが、各試験水準に おいて、良好な結果を得ることができた。

表 1 高力ボルトすべり係数試䄼結果一覧表

\begin{tabular}{|c|c|c|c|c|}
\hline ボルト径 & 中板厚 & 孔径 & 表面処理 & 係数 \\
\hline M22 & 22 & $\$ 24$ & ジンク塗装同士 & 0.564 \\
\hline M22 & 22 & $\phi 26$ & ジンク塗装同士 & 0.552 \\
\hline M22 & 22 & $\phi 24$ & メッキ薬品処理同士 & 0.455 \\
\hline M22 & 22 & $\phi 26$ & メッキ薬品処理同士 & 0.432 \\
\hline M22 & 22 & $\phi 24$ & $\begin{array}{l}\text { 側板 : ジンク塗装 } \\
\text { 中板：メッキ薬品処理 }\end{array}$ & 0.587 \\
\hline M22 & 22 & $\phi 26$ & $\begin{array}{l}\text { 側板 : ジンク染装 } \\
\text { 中板 : メッキ薬品処理 }\end{array}$ & 0.534 \\
\hline M22 & 40 & $\phi 24$ & $\begin{array}{l}\text { 側板 : ジンク塗装 } \\
\text { 中板 : メッキ薬品処理 }\end{array}$ & 0.562 \\
\hline M22 & 40 & $\phi 26$ & $\begin{array}{l}\text { 側板 : ジンク柴装 } \\
\text { 中板 : メッキ処理 }\end{array}$ & 0.586 \\
\hline
\end{tabular}

なお、黒皮ボルトの防錆処理は素地調整が施しにくく、ナット出 隅での膜厚確保が難しいため、2 種ケレンの上、厚膜型エポキシ樹 脂プライマーを 2 度塗りする仕様とした。

\section{2ー5スケジュール管理}

表 2 製作管理項目のスケジュール管理状况

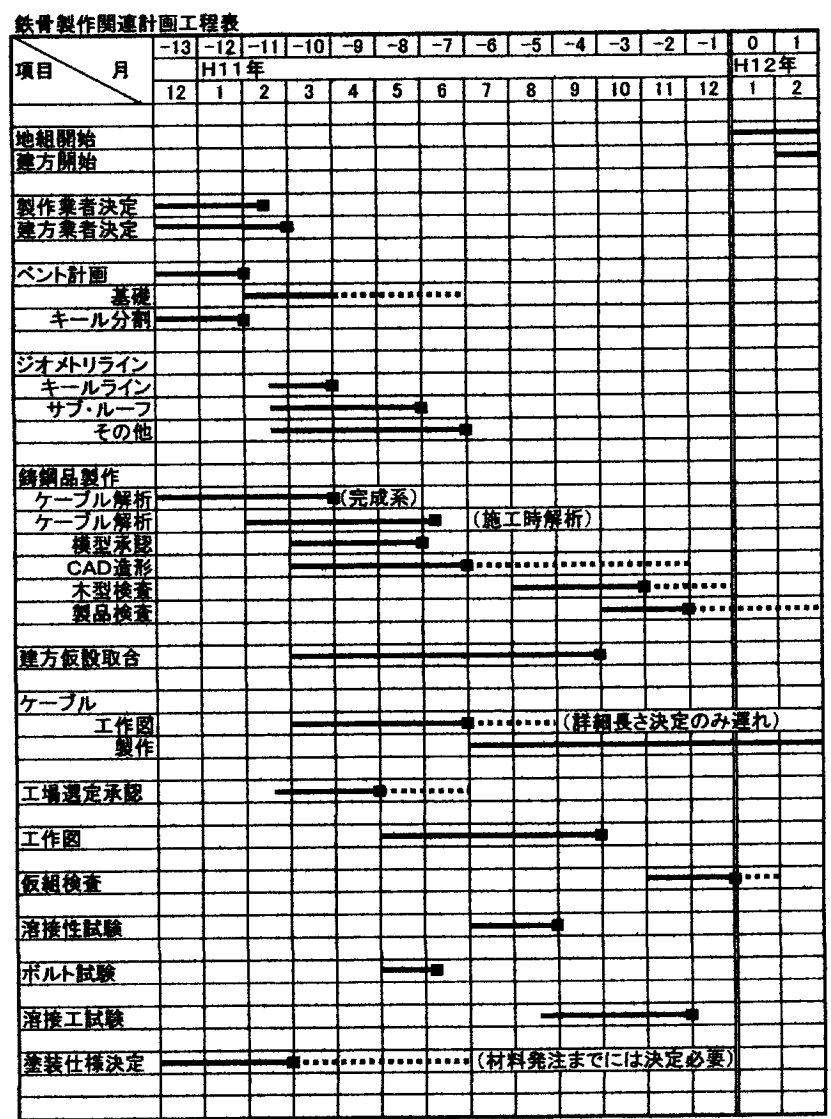

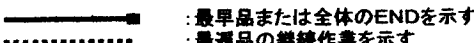

大規模特殊構造物の計画は、建方開始 1 年以上前から決定すべき 重要管理項目があるため、その時期を明確にして管理した。

\section{3、建方施工管理}

3ー1ペント計画

ベント計画は下記の原則を基本方針とした。（図 4 参照）

(1) サブトラスを分割しない (スタンド段床を駄目にしない)

(2) サイドスタンドとの干涉範囲を小さくする。

(3) キールトラス上架時の架構の安定を図る。

(4) ベントをキールトラス上架前でも自立させる。（最高 $60 \mathrm{~m}$ ）

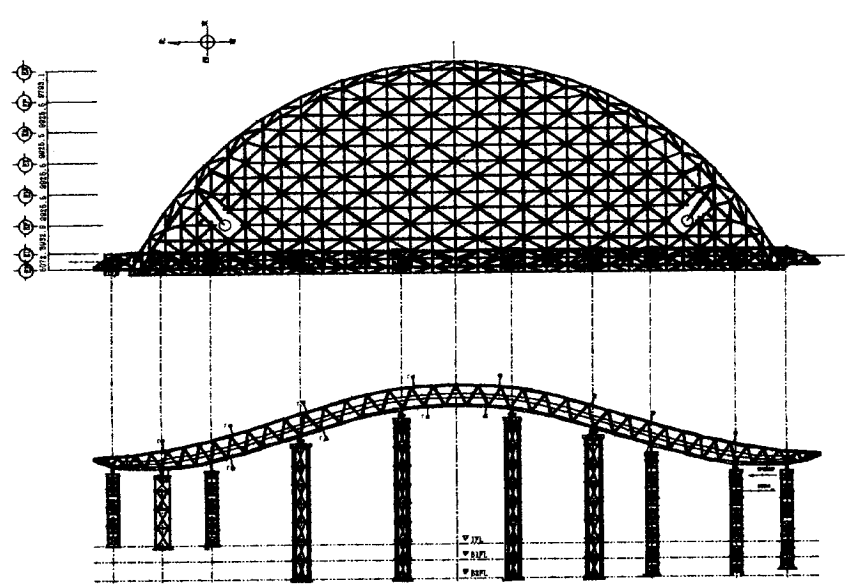

図 4 ベント配置計画図（固定屋根片側を示す。）

\section{3-2 地組针画と地組状況}

フィールド部分で地組を行い、キールトラス用定盤に 4〜6 定盤、 サブトラス用定盤に 3 4 定盤、マスト用定盤に 2 定盤を設置した。 ルーフサポート用定盤はバックスタンド側の建物外周に 3 定盤程度 用意し、メインスタンド側は後施工躯体部分に 3 定盤程度設畐した。

地組工程は組立溶接から中上塗り塗装までとしたため、定盤には 精度を要求する地組定盤と叙装架台の 2 種類を設置した。叙装用架 台は柱を四隅に立て、ワイヤ+飛散荃生シート張とし、塗料飛散防止 に努めた。

定盤の配置は、資材搬入動線、重機作業動線と定期的に調整を行 った。建屋外の外構部分で地組し、横持ち運搬する計画ならば動線 調整は不要となるが、地組用の設備が別途必要となり、工事費の増 加を伴うため、今回の工事では採用しなかった。（図５参照）

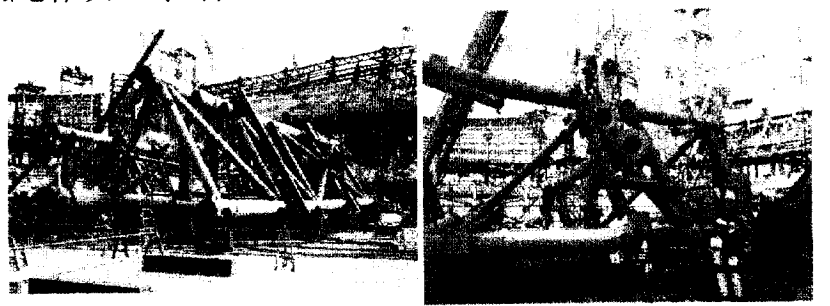

図 5 建屋内でのキールトラス地組状況

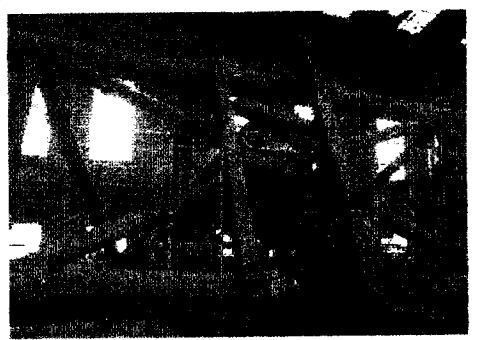

図 6 製作工場でのキールトラス仮組立状況 
現地での地組は、図6に示すように、工場での仮組状況を再現す る形で実施した。

\section{3-3 建方崸序と精度管理}

建方順序は、北側 $1 / 3 \rightarrow$ 南側 $1 / 3 \rightarrow$ 中央 $1 / 3$ の手順とし、中央部 分を最後とした。これは、ベントの低い所から建て始めて架䅹の安 定を図り、建て仕舞を中央の比較的直交している部材で取り合わせ ることにより納め易くするためであった。

最終の中央ブロックの寸法精度（地組精度を含む）は土10 mm 程度 であり、精度良く施工できた。（図 7 参照）

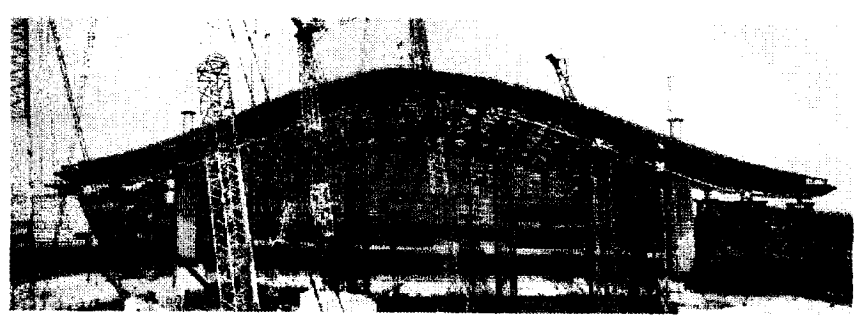

図 7 固定屋根建方完了状況

キールトラス及びサブトラスの地組時に、仕口位瞋を定盤上の睪 書き位面と照合し、個々の建方部材の精度を 1 3 m m の精度で確保 した。(図 8 参照)
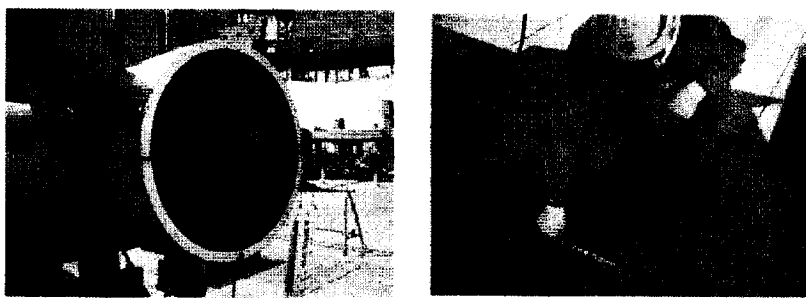

図 8 地租時の精度管理状況

上架時には、キールトラスの地組ユニットの仕口端部に 3 次元測 量器 (マンモス : ソキア製) のターダットを取付けて上架した。（図 9 参照）この際、予め工作図の 3 次元 C AD より、建方時のキール トラスの仕口位膡を 3 次元座標で算出しておき、その座標値に害物 のターゲット位置を合わせるようにして建方精度の管理を実施した。

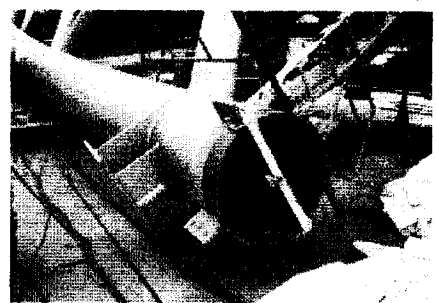

図 93 次元測量器のターゲット設置状况

4. まとめ

湾曲したキールトラスを有する総重量 8,650 t に及ぶ吊り屋根鉄 骨の製作・建方施工管理について述へできが、以下に施工管理上 留意すべき事項を要約する。

(1) ケーブル定着に伴う鋳鋼品の製作は、形状決定の手順が複雑で あり、早期に定着方法を決定し、手順を追って造形検証を進め る必要がある。また、意匠性の高い部品のため、意匠設計者の 造形確認を必要とし、鉄骨製作工程の遅延要素となりやすい。

(2) $60 \mathrm{~kg}$ 級高張力鎆及び鋳銿の溶接計画は、使用条件を考慮した溶 接施工性試験にて検証し決定した。今回は C02 自動または半自 動溶接法によるX型、K型開先継手とすることで良好な溶接施
エを行うことができた。

(3) 製作工場にて現場施工と同条件で仮組立を実施し、現場施工で の再現性を確保した。また、工作図情報は 3 次元 C A D にて座 標変換を行い、予め組立専用の活用しやすい情報として整備し た。

(4) 重防食塗装と亜鉛メッキの混用構造のため、高力ボルト摩擦面 の組合せが 3 種類となった。すべり係数試験を実施し、厚膜型 無機ジンクリッチ塗装同士及びジンクリッチ塗装と亜鉛メッキ 薬品処理面の組合せでは、すべり保数 0.45 を確保できた。

(5) 建方開始 1 年以上前から製作に反映すべき管理項目があるため、 製作時の管理項目の抽出と、決定時期の確認を行い、工程遅延 にならないようにする必要がある。

(6) ベント計画は早い時期に方針決定する必要がある。製作、揚重、 現場施工全ての基本となる。

(7) 地組ヤードを何処に設定するかで、工事計画が大幅に変動する。 地組ヤードを建屋内に設定すると、工程計画が地組架台数と地 組能力によって決定される。また、工程調整は地組ヤードの振 り回しの影整を受けるため、凟材搬入動線や重機走行動線との 調整が複雑になる。

5. 铸辞

今回工事の施工計画、実施工に当たっては、新日本製鐵株式会社 建筑事業部、横河工事株式会社、宮地建設工業株式会社の協力によ り良好な結果を得ることができた。ここに謹んで噺辞を述べたい。

[2001年 4 月 9 日原稿受理 2001年 7 月27日採用決定］ 